\title{
Human-caused Disturbance Stimuli as a Form of Predation Risk
}

\author{
Alejandro Frid ${ }^{1}$ and Lawrence Dill
}

\begin{abstract}
A growing number of studies quantify the impact of nonlethal human disturbance on the behavior and reproductive success of animals. Athough many are well designed and analytically sophisticated, most lack a theoretical framework for making predictions and for understanding why particular responses occur. Behavioral ecologists have recently begun to fill this theoretical vacuum by applying economic models of antipredator behavior to disturbance studies. In this emerging paradigm, predation and nonlethal disturbance stimuli create similar trade-offs between avoiding perceived risk and other fitness-enhancing activities, such as feeding, parental care, or mating. A vast literature supports the hypothesis that antipredator behavior has a cost to other activities, and that this trade-off is optimized when investment in antipredator behavior tracks short-term changes in predation risk. Prey have evolved antipredator responses to generalized threatening stimuli, such as loud noises and rapidly approaching objects. Thus, when encountering disturbance stimuli ranging from the dramatic, lowflying helicopter to the quiet wildlife photographer, animal responses are likely to follow the same economic principles used by prey encountering predators. Some authors have argued that, similar to predation risk, disturbance stimuli can indirectly affect fitness and population dynamics via the energetic and lost opportunity costs of risk avoidance. We elaborate on this argument by discussing why, from an evolutionary perspective, disturbance stimuli should be analogous to predation risk. We then consider disturbance effects on the behavior of individuals — vigilance, fleeing, habitat selection, mating displays, and parental investment — as well as indirect effects on populations and communities. A wider application of predation risk theory to disturbance studies should increase the generality of predictions and make mitigation more effective without over-regulating human activities.
\end{abstract}

\section{INTRODUCTION}

More than 30 years ago, Walther (1969) published an experiment in which he assumed that animals perceive human disturbance similarly to predation risk. Walther approached Thomson's gazelles (Gazella thomsoni) with his car to test whether flight initiation distance (the distance between the predator and prey at which prey begin to flee) depended on age, sex, and social status. He also studied gazelles fleeing from wild dogs (Lycaon pictus) and other predators, and appeared satisfied that the variables affecting responses to a car would have been similar had the stimuli been actual predators (Walther 1969). Walther's experiment was stimulated by the work of Hediger (1934, cited in Walther 1969), who three decades earlier had approached African ungulates with a car to determine interspecific differences in flight initiation distance.

Since these pioneering studies, research on disturbance has begun to embrace the principle that nonlethal disturbance stimuli caused by humans are analogous to predation risk. The notion works because responses both to predation risk (Lima and Dill 1990, Lima 1998) and to disturbance stimuli (e.g., Gutzwiller et al. 1994, Steidl and Anthony 2000) divert time and energy from other fitness-enhancing activities such as feeding, parental care, or mating displays. (In the context of our argument, disturbance denotes a deviation in an animal's behavior from patterns occurring without human influences. We use the term disturbance stimulus for a human-related presence or object [e.g., birdwatcher, motorized vehicle] or sound [e.g., seismic blast] that creates a disturbance.) Animals optimize these trade-offs when their investment in antipredator behavior tracks short-term changes in predation risk (Lima and Dill 1990, Lima 1998). For example, woodchucks (Marmota monax) decrease their flight initiation distance when thry are closer to a refuge burrow (Bonenfant and Kramer 1996); and gray squirrels (Sciuris carolinensis) show the same response when nearer to a refuge tree (Dill and Houtman 1989). Individuals near a refuge that tolerate closer approaches by potential predators avoid

\footnotetext{
${ }^{1}$ Corresponding Author: Behavioural Ecology Research Group, Department of Biological Sciences, Simon Fraser University, Burnaby, B.C., Canada V5A 1S6 Current Address: POB 10357, Whitehorse, YT, Canada,Y1A 7A1
} 
fleeing costs (abandoning a feeding site and expending energy on locomotion) that do little to increase safety (see Ydenberg and Dill 1986). The plasticity of flight initiation distance is based on the same economic principle-optimization of trade-offs - that drives antipredator behavior in general (Lima and Dill 1990, Lima 1998).

When encountering disturbance stimuli, ranging from the dramatic, low-flying helicopter to the quiet wildlife photographer, an animal's response should follow the same economic principles used by prey encountering predators (Berger et al. 1983, Madsen 1994, Gill et al. 1996, 2001, Gill and Sutherland 2000). We call this verbal model the risk-disturbance hypothesis. It predicts that responses by disturbed animals track short-term changes in factors characterizing disturbance stimuli, with responses being stronger when perceived risk is greater. The level of perceived risk may result from a combination of factors that characterize disturbance stimuli, along with factors related to natural predation risk (e.g., Frid 2001a, Papouchis et al. 2001).

Although earlier work (notably, Berger et al. 1983, Madsen 1994) used predation risk as an analogy for understanding human disturbance of wildlife, Gill and Sutherland (2000) explicitly argued that disturbance stimuli and predation risk indirectly affect survival and reproduction through trade-offs between perceived risk and energy intake. Their models predict how densitydependent processes interact with food distribution and disturbance stimuli to determine habitat shifts and population dynamics (Gill et al. 1996, 2001, Gill and Sutherland 2000).

Here we develop the risk-disturbance hypothesis further. We discuss why, from an evolutionary perspective, disturbance stimuli should be analogous to predation risk. Most disturbance studies focus on responses directly related to energy trade-offs: fleeing, vigilance, and habitat selection. We use examples from that rich literature to assess some predictions of the risk-disturbance hypothesis. We also use a predation risk framework to explore four areas in which disturbance effects are less studied: mate acquisition, parental investment, population dynamics, and interactions at the community level. Finally, we evaluate when and how disturbance studies might increase their conservation value by applying the riskdisturbance hypothesis.

\section{ARE DISTURBANCE STIMULI REALLY ANALOGOUS TO PREDATION RISK?}

A devil's advocate might argue that disturbance stimuli are not analogous to predation risk because prey have evolved predator-specific antipredator behaviors (e.g., Walther 1969, Ghalambor and Martin 2000), and many disturbance stimuli (e.g., aircraft) are too recent for animal responses to reflect adaptive programming. However, prey have evolved antipredator responses to generalized threatening stimuli, such as loud noises and rapidly approaching objects (e.g., Dill 1974a, b). Prey respond when such stimuli cross a threshold, even when the specific source is new to the prey's evolutionary history (e.g., introduced predators or motorized vehicles). The zebra danio (Brachydanio rerio), a small fish, provided one extreme example when exposed to real predators (largemouth bass: Micropterus salmoides), a predatorshaped model, and a 'cinematographic' predator (a film of a black dot increasing in size, simulating an approaching object). In all three cases, danios fled when the angle subtended by the predator at the prey's eye reached a threshold rate of change ( see Appendix 1). This threshold 'loom' rate depended on the size and speed of the approaching 'predator', and responses were qualitatively similar for the different 'predator' types. In other words, danios appeared to decide the timing of fleeing by relating the loom rate to a margin of safety, regardless of whether the predator was real, a model, or a film (Dill 1974a, b).

A devil's advocate might also argue that predation risk and disturbance stimuli are not analogous because disturbed animals do not necessarily risk direct mortality. The counter-argument is that it is irrelevant if disturbance stimuli are nonlethal because predation risk differs from predation itself. Although death is the outcome of predation, the outcome of predation risk is a decision made by prey to compromise the rate of resource acquisition or other activities to reduce the probability of death (Abrams 1993, Hugie and Dill 1994, review in Lima 1998). Specifically, predation risk results from the interaction of factors that affect attack and capture probabilities, mainly (1) the structure of the environment, including the distribution of vegetation cover where predators might hide and of refuges where prey might escape, (2) social factors, including the prey's group size and position in the group, (3) the distribution and abundance of predators, and (4) the behavior of predators (whether they are searching for and selecting a given prey type). Because antipredator behavior responds to changes in these 
factors rather than to predation rate per se, it is reasonable to expect responses to nonlethal disturbance stimuli to follow the same decision rules as responses to predation risk.

Does habituation invalidate this premise? Shouldn't prey that behave optimally recognize that nonlethal stimuli do not warrant the costs of antipredator behavior? Animals rarely have perfect information, and generally are expected to maximize fitness by overestimating rather than underestimating risk. Overestimation costs, such as lost feeding opportunities, have milder fitness consequences than the cost of underestimating danger, which might be immediate death (Bouskila and Blumstein 1992). Thus, habituation to disturbance stimuli, although it generally occurs to some extent, often is partial (e.g., Burger and Gochfeld 1981, 1990, Steidl and Anthony 2000) or negligible (e.g., Berger et al. 1983, Bleich et al. 1994). It is unlikely to disprove the risk-disturbance hypothesis in most situations, even for animals that provide archetypal examples of habituation, such as urban corvids (Ward and Low 1997). Furthermore, there are instances in which antipredator-type responses to nonlethal stimuli should become stronger with repeated exposure to such stimuli. For example, prey learn to associate the low loom rate of an approaching predator that is still far away with the faster loom rate that occurs once the predator is closer. Thus, flight initiation distance or vigilance might increase with repeated exposure to a nonlethal stimulus if the latter is sufficiently aversive (Dill 1974b).

A final issue to consider is that human hunters have represented a real threat to some species over evolutionary time. Thus, in some cases such as people on foot approaching large vertebrates, disturbance stimuli and true predatory stimuli may be indistinguishable from the animal's perspective.

\section{TRADE-OFFS DIRECTLY RELATED TO ENERGY GAIN}

We next use the rich literature dealing with disturbance effects on fleeing, vigilance, and habitat shifts to assess some predictions of the riskdisturbance hypothesis. Our assessment is not a quantitative test based on a random sample of the literature, which could be biased by failure to publish negative results. Rather, it is based on selected references and is meant to demonstrate the explanatory value of the hypothesis and to stimulate future studies explicitly designed to test its predictions. We have not included all examples known to us, but only enough to illustrate our arguments.

\section{Fleeing}

Prey that have detected a potential predator should make optimal fleeing decisions that balance the benefits of reducing capture probability against the costs of abandoning a resource patch and expending energy on locomotion (Ydenberg and Dill 1986). Fleeing probability should increase when the predator approaches more directly, because a direct approach may convey detection and intent to capture (Burger and Gochfeld 1981, 1990, Cooper 1997, 1998). Although the angle of approach is two-dimensional in some systems (e.g., terrestrial animals on flat ground), in others it has horizontal and vertical components. For instance, an aerial predator may change the approach angle by shifting its elevation relative to prey (rather than lateral distance). The same principle applies to aircraft disturbance, or when ground disturbance stimuli approach animals on landscapes with a vertical dimension (e.g., mountain slopes, trees). The angle of approach is a geometric correlate of the nearest distance between the trajectory of the approaching stimulus and the animal being approached. Thus, greater distances (lateral and vertical) correspond to larger angles and less direct approaches. Angles are more difficult to measure than distances, and most field studies quantify the latter.

Fleeing probability or flight initiation distance should increase when predators are larger or approach faster because prey will experience the loom rate that triggers flight at greater distances (Dill 1974a). Flight initiation distance increases as distance to a refuge becomes greater because risk of capture increases (Ydenberg and Dill 1986, Dill and Houtman 1989, Bonenfant and Kramer 1996). Prey may also respond to predator group size. For instance, Thomson's gazelles had smaller flight initiation distances when approached by single hyenas (Crocuta crocuta) than when approached by packs (Walther 1969). Flight initiation distance and fleeing probability also increase when prey are at a site that is poor in resources (e.g., little food), because the benefits of clinging to a resource patch are less likely to outweigh the risk of remaining (see data on waterstriders, Gerris remiges, in Ydenberg and Dill 1986). 
Predictions of the risk-disturbance hypothesis stimulated by studies of fleeing responses to predators include the following. Fleeing probability and flight initiation distance increase when disturbance stimuli (A) approach more directly, (B) approach more quickly, and (C) are larger in size. They also increase when (D) distance from refuge is greater, (E) group size of the disturbers is greater, and $(\mathrm{F})$ the costs of fleeing are lower. Lower fleeing costs might arise when the resource patch is poor (i.e., less is lost by leaving), rich resources are evenly distributed and easy to locate elsewhere, or environmental conditions (temperature, snow depth) are mild at the time of disturbance, thereby not increasing locomotion costs (see Ydenberg and Dill 1986). We did not consider obstructive cover because it represents a constraint to early detection rather than an influence on the decision to withhold fleeing. Also, we did not consider the effects of group size of disturbed animals, which are difficult to predict due to the opposing effects of dilution and additional sensory organs (Ydenberg and Dill 1986).

Reviewed studies were consistent with Prediction A. Fleeing probability increased for Dall's sheep Ovis dalli dalli (Frid 2001a, b), ringed seals Phoca hispida (Born et al. 1999), and Pacific Brant Branta bernicla nigricans, and Canada Geese B. canadensis (Ward et al. 1999) as a helicopter or fixed-wing aircraft approached more directly. Bald eagles (Haliaeetus leucocephalus) perched on trees alongside a river were more likely to flee from a paddle raft when perches were closer to the river or lower in height (Steidl and Anthony 1996). Table 1 summarizes these and additional examples.

Table 1. Literature examples for assessing predictions concerning fleeing responses. Predictions were that fleeing probability or flight initiation distance increase when disturbance stimuli (A) approach more directly, (B) approach more quickly, and (C) are larger in size. They also increase when (D) distance from refuge is greater, (E) group size of disturbers is greater, and (F) fleeing costs are lower (see Fleeing for details).

\begin{tabular}{|c|c|c|c|c|c|}
\hline \multirow[t]{2}{*}{ Study } & \multirow[t]{2}{*}{ Species } & \multirow[t]{2}{*}{ Stimuli } & \multicolumn{3}{|c|}{ Predictions } \\
\hline & & & Supported & Rejected & $\begin{array}{c}\text { Not tested or } \\
\text { controls lacking }\end{array}$ \\
\hline Born et al. (1999) & ringed seal & $\begin{array}{c}\text { helicopter and fixed- } \\
\text { wing aircraft }\end{array}$ & $\mathrm{A}, \mathrm{F}$ & & $\mathrm{B}, \mathrm{C}, \mathrm{D}, \mathrm{E}$ \\
\hline Burger (1998) & Common Tern & motorized watercraft & $\mathrm{A}, \mathrm{B}$ & & $\mathrm{C}, \mathrm{D}, \mathrm{E}, \mathrm{F}$ \\
\hline \multirow[t]{2}{*}{$\begin{array}{l}\text { Burger and } \\
\text { Gochfeld (1998) }\end{array}$} & $\begin{array}{l}\text { Louisiana and } \\
\text { Little Blue } \\
\text { Herons }\end{array}$ & people on foot & $\mathrm{A}, \mathrm{E}$ & & $\mathrm{B}, \mathrm{C}, \mathrm{D}, \mathrm{F}$ \\
\hline & $\begin{array}{c}\text { other waterbird } \\
\text { spp. }\end{array}$ & & $\mathrm{A}$ & E & $\mathrm{B}, \mathrm{C}, \mathrm{D}, \mathrm{F}$ \\
\hline $\begin{array}{l}\text { Delaney et al. } \\
\text { (1999) }\end{array}$ & $\begin{array}{c}\text { Mexican Spotted } \\
\text { Owl }\end{array}$ & helicopter & $\mathrm{A}, \mathrm{F}$ & & $\mathrm{B}, \mathrm{C}, \mathrm{D}, \mathrm{E}$ \\
\hline Frid $(2001 a, b)$ & Dall’s sheep & $\begin{array}{l}\text { helicopter, fixed- } \\
\text { wing aircraft }\end{array}$ & A, D & & $\mathrm{B}, \mathrm{C}, \mathrm{E}, \mathrm{F}$ \\
\hline $\operatorname{Hamr}(1988)$ & chamois & hikers, skiers & $\mathrm{E}, \mathrm{F}$ & & $\mathrm{A}, \mathrm{C}, \mathrm{B}, \mathrm{D}$ \\
\hline Lafferty (2001) & Snowy Plover & people on foot & $\mathrm{A}$ & $\mathrm{B}, \mathrm{E}$ & $\mathrm{C}, \mathrm{D}, \mathrm{F}$ \\
\hline $\begin{array}{l}\text { Papouchis et al. } \\
\text { (2001) }\end{array}$ & bighorn sheep & $\begin{array}{l}\text { hikers, bikers, } \\
\text { vehicles }\end{array}$ & A, D & $\mathrm{E}$ & $\mathrm{B}, \mathrm{C}, \mathrm{F}$ \\
\hline $\begin{array}{l}\text { Steidl and } \\
\text { Anthony (1996) }\end{array}$ & Bald Eagle & paddle raft & $\mathrm{A}^{*}$ & $A^{*}$ & $\mathrm{~B}, \mathrm{C}, \mathrm{D}, \mathrm{E}, \mathrm{F}$ \\
\hline $\begin{array}{l}\text { Swarthout and } \\
\text { Steidl (2001) }\end{array}$ & $\begin{array}{c}\text { Mexican Spotted } \\
\text { Owl }\end{array}$ & single hiker & A & & $\mathrm{B}, \mathrm{C}, \mathrm{D}, \mathrm{E}, \mathrm{F}$ \\
\hline Ward et al. (1999) & $\begin{array}{l}\text { Pacific Brant and } \\
\text { Canada Goose }\end{array}$ & $\begin{array}{l}\text { helicopter and fixed- } \\
\text { wing aircraft }\end{array}$ & $\mathrm{A}$ & & $\mathrm{B}, \mathrm{C}, \mathrm{D}, \mathrm{E}, \mathrm{F}$ \\
\hline
\end{tabular}

*The prediction was supported for fleeing probability, but not flight initiation distance. 
Flight initiation distance has been found to increase as lateral distance from the disturbance stimulus becomes greater (e.g., Steidl and Anthony 1996, Frid $2001 a$. These results apparently reject prediction A, but geometric correlations could confound interpretation. Flight initiation distance cannot be smaller than the nearest distance between the animal and the trajectory of the stimulus. Thus, if animals flee when the stimulus is nearest to them, flight initiation distance during indirect approaches will always be larger than during direct approaches. Future analyses need to consider potential artifacts that could arise from this geometric correlation.

Support for Prediction B was inconsistent (Table 1). Supporting the prediction, more Common Terns (Sterna hirundo) fled their nests when motorized watercraft approached more quickly (Burger 1998). Contradicting the expectation that earlier fleeing is triggered by a higher velocity (Dill 1974a, joggers were less disturbing to Western Snowy Plovers (Charadrius alexandrinus nivosus) than were people walking, even after distance to the stimulus was controlled (Lafferty 2001). Future work should analyze whether, under certain conditions, slower disturbance stimuli are analogous to a stalking predator and are perceived as more damgerous than a faster stimulus.

We could not evaluate Prediction C. Although comparisons exist between the effects of aircraft of different sizes, noise level is an important covariate (e.g., Ward et al. 1999) that probably confounds size effects.

The two reviewed studies with relevant data supported Prediction D (Table 1). During indirect approaches by helicopters, Dall's sheep far from rocky slopes were much more likely to flee than were sheep on rocky slopes (Frid 2001a,), which provide a refuge from cursorial predators (e.g., Berger 1991). Distance from a refuge probably affects how sheep perceive risk from the generalized stimulus of a large object approaching rapidly, rather than from a perceived aerial predator per se. Ground disturbance had similar effects: bighorn sheep (Ovis canadensis) disturbed by hikers, bikers, or road traffic had stronger fleeing responses when farther from rocky slopes (Papouchis et al. 2001).

Support for Prediction E was inconsistent (Table 1). Little Blue Heron (Egretta caerulea) and Louisiana Heron (E. tricolor) were more likely to flee when birdwatchers were in larger groups. Other species of waterbirds, however, did not respond to disturber group size (Burger and Gochfeld 1998). Flight initiation distance and distances fled by chamois (Rupicapra rupicapra) approached by hikers increased with hiker group size (Hamr 1988). Disturber group size of hikers, mountain bikers, and vehicles did not influence fleeing responses by bighorn sheep, however (Papouchis et al. 2001).

Several studies were consistent with Prediction F (Table 1). Ringed seals disturbed by aircraft were more likely to abandon a haul-out site on the ice pack and dive into the sea when the thermal benefits of staying hauled out were lower due to higher wind chill (Born et al. 1999). Mexican Spotted Owls (Strix occidentalis lucida) did not flee from helicopters when attending young at their nest, but fled readily during the postfledging period (Delaney et al. 1999). Chamois were more reluctant to flee when deep snow entailed a high cost to locomotion (Hamr 1988).

\section{Vigilance and related activity shifts}

A vast literature indicates that prey are more vigilant when the perceived risk of predation is greater. This response increases the chances that the prey will avoid capture, but at the cost of reducing time spent foraging or engaged in other activities. Antipredator vigilance responds not only to the mere presence or absence of predators, but also to factors affecting the level of perceived risk, including group size, distance from a refuge, and obstructive cover (see reviews in Elgar 1989, Lima 1998).

Studies of antipredator vigilance, as well as our discussion on angle of approach from the previous section, stimulated the following predictions. More time is spent vigilant, or less time is spent foraging or resting, when disturbance stimuli (A) approach more directly, (B) remain at closer distances, (C) have a greater group size (e.g., more ecotourists), and (D) occur concurrently with a greater level of natural predation risk (e.g., animals are in smaller groups, closer to obstructive cover, farther from refuge).

The reviewed studies were consistent with Prediction A (Table 2). For instance, vigilance responses or disruptions of resting and foraging by bighorn sheep (Stockwell et al. 1991), Dall's sheep (Frid 2001b,) began earlier and lasted longer when aircraft approached more directly. 
Table 2. Literature examples for assessing predictions concerning vigilance responses. Predictions were: more time is spent vigilant or less time is spent foraging or resting when disturbance stimuli (A) approach more directly, (B) remain at closer distances, (C) have a greater group size (e.g., more ecotourists), and (D) occur concurrently with a greater level of natural predation risk (see the Vigilance section for details).

\begin{tabular}{|c|c|c|c|c|c|}
\hline \multirow[b]{2}{*}{ Study } & \multirow[b]{2}{*}{ Species } & \multirow[b]{2}{*}{ Stimuli } & \multicolumn{3}{|c|}{ Predictions } \\
\hline & & & Supported & Rejected & $\begin{array}{c}\text { Not tested or } \\
\text { controls lacking }\end{array}$ \\
\hline $\begin{array}{l}\text { Burger and } \\
\text { Gochfeld (1998) }\end{array}$ & $\begin{array}{c}\text { several } \\
\text { waterbird spp. }\end{array}$ & people on foot & $\mathrm{C}$ & & A, B, D \\
\hline $\begin{array}{l}\text { Duchesne et } \\
\text { al. (2000) }\end{array}$ & $\begin{array}{l}\text { woodland } \\
\text { caribou }\end{array}$ & $\begin{array}{l}\text { people on skis or } \\
\text { snow shoes }\end{array}$ & $\mathrm{C}$ & & A, B, D \\
\hline Frid $(2001 b)$ & Dall's sheep & $\begin{array}{l}\text { fixed-wing } \\
\text { aircraft }\end{array}$ & A & & $\mathrm{B}, \mathrm{C}, \mathrm{D}$ \\
\hline $\begin{array}{l}\text { Galicia and } \\
\text { Baldassarre } \\
\text { (1997) }\end{array}$ & $\begin{array}{l}\text { American } \\
\text { Flamingo }\end{array}$ & motorboat & $\mathrm{C}$ & $\mathrm{B}$ & A, D \\
\hline $\begin{array}{l}\text { Papouchis et } \\
\text { al. (2001) }\end{array}$ & bighorn sheep & cars, bikes & $\mathrm{C}$ & & A, B, D \\
\hline $\begin{array}{l}\text { Stockwell et } \\
\text { al. (1991) }\end{array}$ & bighorn sheep & helicopter & A & & $\mathrm{B}, \mathrm{C}, \mathrm{D}$ \\
\hline $\begin{array}{l}\text { Ward and } \\
\text { Low (1997) }\end{array}$ & $\begin{array}{c}\text { American } \\
\text { Crow }\end{array}$ & $\begin{array}{l}\text { urban pedestrians } \\
\text { and traffic }\end{array}$ & $\mathrm{B}, \mathrm{D}$ & & $\mathrm{A}, \mathrm{C}$ \\
\hline
\end{tabular}

Support for Prediction B was inconsistent (Table 2). Crows (Corvus brachyrhynchos) in urban environments were more vigilant and foraged less efficiently where disturbance stimuli were nearer (Ward and Low 1997), but American Flamingos (Phoenicopterus ruber ruber) were more vigilant when motorized tourboats were farther away (Galicia and Baldassarre 1997).

Several studies were consistent with Prediction C (Table 2). For instance,larger groups of people on foot had stronger effects on vigilance increases by both birds and ungulates (Burger and Gochfeld 1998, Duchesne et al. 2000).

Consistent with Prediction D, vigilance by crows following urban disturbance stimuli was affected by distance to obstructive cover and flock size (both positive relationships). Vigilance was also inversely related to distance to protective cover (Ward and Low 1997).

\section{Habitat selection}

Habitat choice is the outcome of decisions that balance the trade-off between predation risk and resource richness. Theoretically, animals should select habitats that minimize the ratio of mortality risk to net energy intake (Gilliam and Fraser 1987, reviews in Lima and Dill 1990, Lima 1998). Consistent with theory, individuals of taxa as diverse as fish (e.g., Gilliam and Fraser 1987), ungulates (e.g., Edwards 1983, Berger 1991), and small mammals (Morris and Davidson 2000) spend less time in places where richer resources are associated with greater danger. Whether animals under risk shift their habitats depends on the relative costs and benefits of leaving their current site and going elsewhere. Such decisions may be constrained by the species' perceptual range, the distance from which individuals can perceive key landscape elements (Lima and Zollner 1996, Zollner and Lima 1997).

Gill et al. (2001) use a predation risk framework to argue that animals that do not shift habitats when exposed to disturbance stimuli might have no suitable 
alternative habitats. Thus, animals are still impacted by being forced to remain at disturbed sites where the increased energetic costs of antipredator behavior reduce effective habitat quality.

Predictions regarding habitat selection, which have been proposed previously by disturbance studies grounded in predation risk theory, include the following. (A) Long-term, intense disturbance stimuli will cause habitat shifts (or observed avoidance of disturbed habitats when pre-treatment data are not available) at the cost of reduced access to resources. A different form of the prediction is that animals will access resources in habitats previously affected by disturbance stimuli once the latter are removed (Madsen 1994, 1998, Gill et al. 1996, Gill and Sutherland 2000). (B) Habitat shifts will not occur if alternative habitats are too distant or of low quality, such that the net benefits of shifting habitats do not outweigh the costs of remaining at disturbed sites (Gill et al. 2001).

Almost all of the reviewed studies strongly supported Prediction A, implying that alternative habitats were available in those systems (Gill et al. 2001). The pygmy marmoset (Cebuella pygmaea), a neotropical primate, shifted to the upper canopy in areas disturbed by ecotourists on foot and motorboats, but used the lower strata (which it normally prefers) in less disturbed areas (de la Torre et al. 2000). Available habitat and access to food were substantially reduced for disturbed Pink-footed Geese (Anser brachyrhynchus; Gill et al. 1996). For woodland caribou (Rangifer tarandus caribou) during late winter, functional habitat loss caused by avoidance of roads and other developments amounted to $48 \%$ of a $6000-\mathrm{km}^{2}$ study area (Dyer et al. 2001). Bottlenose dolphins (Tursiops truncatus) avoided important foraging areas when motorboat traffic was high (Allen and Read 2000). Table 3 summarizes these and additional examples. Such habitat shifts probably increase the strength of density-dependent processes (e.g., intraspecific competition) that affect demography (Gill and Sutherland 2000).

In contradiction to Prediction A, woodland caribou shifted habitats in response to wolves (Canis lupus), but not in response to people on skis and snowshoes (they did suffer costs to foraging and resting: Duchesne et al. 2000). Alternative habitat may have been of low quality and not worth shifting to without a very high risk of wolf predation. Unfortunately, Prediction B was not tested.

Consistent with Prediction B, diving ducks (mainly Aythya spp.) at a bay on Lake Erie fled from motorboats and promptly returned to the bay during spring, but during fall often redistributed into the adjacent and very large main lake. Spring was correlated with harsher conditions and partial ice cover on Lake Erie, which probably reduced the benefits of shifting habitats.

In contrast, the lake was suitable alternative habitat during fall, when habitat shifts did occur (Knapton et al. 2000). Similarly, Florida manatees (Trichechus manatus latirostris) during winter continued to use a bay with thermal springs (an essential resource for avoiding hypothermia) and did not shift into colder waters outside the bay, regardless of very high levels of boat traffic. At a smaller spatial scale and consistent with Prediction A, they selected areas within the bay with the least boat traffic (Buckingham et al. 1999).

\section{ACQUIRING MATES}

Individuals of many taxa signal to attract mates or warn off intruders to their territories, but such advertisement can attract predators (see reviews in Lima and Dill 1990, Magnhagen 1991, Lima 1998). Male Tungara frogs (Physalaemus pustulosus) are a classic example because their chorusing attracts both potential mates and predatory bats (Trachops cirrhosus). Frog responses to a model bat flying above their pond ranged from silencing mating calls but remaining on the pond's surface, to abandoning the site by diving (stronger responses corresponded to more direct approaches). The cost of safety was postponed access to mates (Ryan 1985).

Disturbance stimuli may cause similar trade-offs. Passerine birds sing to defend territories or attract mates; Gutzwiller et al. (1994) reported that some species (but not all) reduced their singing activity when humans walked through or near their territories. Relative to areas with little disturbance, pygmy marmosets in areas used intensely by ecotourists (on foot and in motorboats) had a lower frequency of trills, a display that serves to maintain contact with social groups and that might affect mate acquisition (de la Torre et al. 2000). 
Table 3. Literature examples for assessing predictions concerning habitat shifts. Predictions (in shortened form; see text for more detail) were (A) long-term, intense disturbance stimuli will cause habitat shifts at the cost of reduced access to resources, but (B) habitat shifts will not occur if alternative habitats are unavailable or unsuitable. Unless both treatments are addressed, support for Prediction A makes Prediction B inapplicable. (See Habitat selection.)

\begin{tabular}{|c|c|c|c|c|c|}
\hline \multirow[b]{2}{*}{ Study } & \multirow[b]{2}{*}{ Species } & \multirow[b]{2}{*}{ Stimuli } & \multicolumn{3}{|c|}{ Predictions } \\
\hline & & & Supported & Rejected & $\begin{array}{l}\text { Not tested or } \\
\text { controls lacking }\end{array}$ \\
\hline $\begin{array}{l}\text { Allen and Read } \\
(2000)\end{array}$ & $\begin{array}{l}\text { bottlenose } \\
\text { dolphin }\end{array}$ & motorboats & A & & \\
\hline $\begin{array}{l}\text { Buckingham et al. } \\
\text { (1999) }\end{array}$ & $\begin{array}{l}\text { Florida } \\
\text { manatee }\end{array}$ & $\begin{array}{l}\text { motor and paddle } \\
\text { boats }\end{array}$ & A, B & & \\
\hline $\begin{array}{l}\text { de la Torre et al. } \\
(2000)\end{array}$ & $\begin{array}{l}\text { pygmy } \\
\text { marmoset }\end{array}$ & $\begin{array}{l}\text { people on foot and } \\
\text { boats }\end{array}$ & A & & \\
\hline $\begin{array}{l}\text { Duchesne et al. } \\
(2000)\end{array}$ & $\begin{array}{l}\text { woodland } \\
\text { caribou }\end{array}$ & $\begin{array}{l}\text { people on skis or } \\
\text { snow-shoes }\end{array}$ & & A & B \\
\hline Dyer et al. (2001) & $\begin{array}{l}\text { woodland } \\
\text { caribou }\end{array}$ & $\begin{array}{l}\text { roads, other linear } \\
\text { developments }\end{array}$ & A & & \\
\hline Gill et al. (1996) & $\begin{array}{l}\text { Pink-footed } \\
\text { Geese }\end{array}$ & $\begin{array}{l}\text { roads, vehicular } \\
\text { traffic, related } \\
\text { activities }\end{array}$ & A & & \\
\hline $\begin{array}{l}\text { Knapton et al. } \\
(2000)\end{array}$ & $\begin{array}{l}\text { diving } \\
\text { ducks }\end{array}$ & motorboats & A, B & & \\
\hline Lafferty (2001) & $\begin{array}{l}\text { Snowy } \\
\text { Plover }\end{array}$ & people on foot & A & & \\
\hline Lord et al. (1997) & $\begin{array}{l}\text { New Zealand } \\
\text { Dotterel }^{\mathrm{a}}\end{array}$ & people on foot & A & & \\
\hline Mace et al. (1996) & $\begin{array}{l}\text { grizzly } \\
\text { bear }\end{array}$ & $\begin{array}{l}\text { roads, vehicular } \\
\text { traffic, related } \\
\text { activities }\end{array}$ & A & & \\
\hline Madsen (1998) & $\begin{array}{l}\text { waterfowl (quarry } \\
\text { and non-quarry } \\
\text { species) }\end{array}$ & hunting activities & A & & \\
\hline $\begin{array}{l}\text { Nellemann and } \\
\text { Cameron (1998) }\end{array}$ & $\begin{array}{l}\text { barren-ground } \\
\text { caribou }\end{array}$ & $\begin{array}{l}\text { road density and } \\
\text { associated activities }\end{array}$ & A & & \\
\hline $\begin{array}{l}\text { Nellemann et al. } \\
(2000,2001) \text {, } \\
\text { Vistness and } \\
\text { Nellemann (2001) }\end{array}$ & reindeer $^{\mathrm{b}}$ & $\begin{array}{l}\text { road traffic; centers } \\
\text { of human activity }\end{array}$ & A & & \\
\hline $\begin{array}{l}\text { Papouchis et al. } \\
(2001)\end{array}$ & $\begin{array}{l}\text { Bighorn } \\
\text { sheep }\end{array}$ & road traffic & A & & \\
\hline
\end{tabular}


For some lekking species, such as the Great Snipe (Gallinago media), both disturbance stimuli and predation risk can cause males to flee from a lek. These males must then choose between returning to the lek at the risk of re-encountering the predator, or losing access to females by continuing to hide. Males with a high mating probability are more likely to risk returning sooner (Kålås et al. 1995). Yet consider the likely case of an ecotourist who, after disrupting a lek, remains in place determined for another photograph, forcing lek members to hide longer and precluding matings for that period.

The potential impact of ecotourism on the reproductive success of lekking ungulates was discussed almost 30 years ago by McTaggart-Cowan (1974). Walther (1969) also warned that female Thomson's gazelles, whose flight initiation distance from a car is greater than that of males, would be unable to access male territories found within areas frequented by ecotourists. Although data are lacking, it is likely that human divers intent on photographing or viewing reef fishes often disrupt mating by displacing fish from their territories.

\section{PARENTAL INVESTMENT}

Predation risk can impact reproduction via decisions about parental investment. When predators threaten both offspring and the parent, should the parent defend the young and face potential death, or should it flee and expect future reproduction to outweigh the loss of current offspring? The decision depends on the parent's residual reproductive value. Parents of iteroparous species that produce few young per year but have long reproductive life-spans should be more likely to save themselves and abandon their current offspring, thus maintaining options for future reproduction (reviews in Clutton-Brock and Godfray 1991, Magnhagen 1991).

Disturbance stimuli may create similar trade-offs. If parents chose to desert young, however, offspring mortality may result from physical factors (e.g., cold temperatures) or facilitation of real predators, and not directly from the disturbance stimuli that threatened the parent. For example, during helicopter disturbance, a Dall's sheep lamb straying behind its fleeing mother fell prey to a Golden Eagle (Aquila chrysaetos; Nette et al. 1984). Many bird studies found that nestling predation increased when parents disturbed by humans abandoned the nest (e.g., Tremblay and Ellison 1979,
Anderson 1988, Piatt et al. 1990). Further support is found in the lower survival rates of mountain goat (Oreamnos americanus) kids separated from their mother during disturbance events (caused by helicopter overflights or all-terrain vehicles) or during encounters with grizzly bears (Ursus arctos; Côté and Beaudoin 1997).

When a predator threatens offspring but not the parent, the parent may face a trade-off between energy gain and offspring protection. For Seychelles Warblers (Foudia sechellarum), nest guarding by males brings a seven-fold reduction in the rate of egg losses to predation, but time spent nest guarding is time not spent provisioning young or self-feeding. Such tradeoffs may not only cause current offspring to starve, but also impact the parents' body condition and future reproduction (Komdeur and Kats 1999).

Parental investment theory should guide predictions of when disturbance stimuli will cause parent-offspring separation, thereby indirectly increasing predation rates on young (see Ghalambor and Martin 2000). Consider female bears (U. arctos, U. maritimus, and $U$. americanus) with vulnerable offspring hibernating inside dens. Costs of den abandonment can be high (one study reports a 10-fold increase in cub mortality) and a variety of disturbance stimuli, including seismic blasts, may cause den abandonment. Responses of individual mothers, however, are variable (review in Linnell et al. 2000). Could the probability of den abandonment be predicted in terms of the mother's residual reproductive value?

Although Clark and Ydenberg (1990) provide a framework for quantitative predictions, some qualitative predictions derived from parental investment theory are as follows: (A) When disturbance stimuli are very strong (e.g., direct approaches by helicopters, nearby seismic blasts) and vulnerable young cannot flee, parents with high residual reproductive value will be more likely to desert their young than parents that have already fulfilled most of their reproductive potential. (B) When young are not abandoned and disturbed parents increase their vigilance, hiding, or protection of young, parents with low residual reproductive value will compromise provisioning less than self-feeding, while parents with high residual reproductive value will do the opposite.

We did not find studies that could evaluate these predictions beyond indicating that disturbance does alter provisioning and self-feeding rates. Bald Eagles 
disturbed by campers increased the time spent protecting nestlings; consequently, the amount of prey consumed during provisioning and self-feeding dropped by almost one-third (Steidl and Anthony 2000). Mexican Spotted Owls decreased prey delivery rates after disturbance from helicopters and chainsawrelated noise, and the effect was stronger when stimuli approached more closely (Delaney et al. 1999). European Oystercatchers (Haematopus ostralegus) decreased the time spent incubating eggs, self-feeding, and provisioning young when disturbed by people on foot (Verhulst et al. 2001). Testing the effects of residual reproductive value is more difficult and would require studies of marked individuals of known ages.

\section{INDIRECT EFFECTS ON POPULATIONS}

High levels of predation risk may indirectly affect survival and reproduction by causing prey to divert a large proportion of time and energy away from resource acquisition, so that body condition deteriorates and survival and reproductive success are reduced (Hik 1995, review in Lima 1998, Morris and Davidson 2000). Furthermore, as proposed by the Predation-Sensitive Foraging Hypothesis (Sinclair and Arcese 1995), animals in poor condition may experience greater predation rates when trying to avoid starvation by searching for additional food in dangerous habitats (McNamara and Houston 1987, Hik 1995, Sinclair and Arcese 1995, Sweitzer 1996).

Although only predation causes direct mortality, both predation risk and disturbance stimuli potentially affect population dynamics indirectly by altering an individual's investment in antipredator behavior (reviews in Lima 1998, Gill and Sutherland 2000). If the response includes shifting habitats, then animals displaced from disturbed sites may experience greater intraspecific competition when forced to spend more time in suboptimal habitats, or when crowding into the small areas of good habitat that remain undisturbed (Gill and Sutherland 2000). In some systems, such redistribution in response to disturbance stimuli might also enhance the hunting success of real predators (Kilgo et al. 1998; but see Brown et al. 1999 and next section).

As outlined in Fig. 1, the risk-disturbance hypothesis predicts that long-term and intense disturbance stimuli can cause population declines via reduced body condition and consequent reductions in reproductive success, particularly during periods of high environmental stress (White 1983, Madsen 1994). Reduced body condition caused by high disturbance levels could also contribute to increased predation rates (Fig. 1; see Sinclair and Arcese 1995).

Fig. 1. Conceptual model outlining the behavioral mechanisms by which increased rates of human disturbance or of predator encounters by prey could cause population size to decline. Downward-facing arrows inside boxes indicate a negative response and upward-facing arrows indicate a positive response.

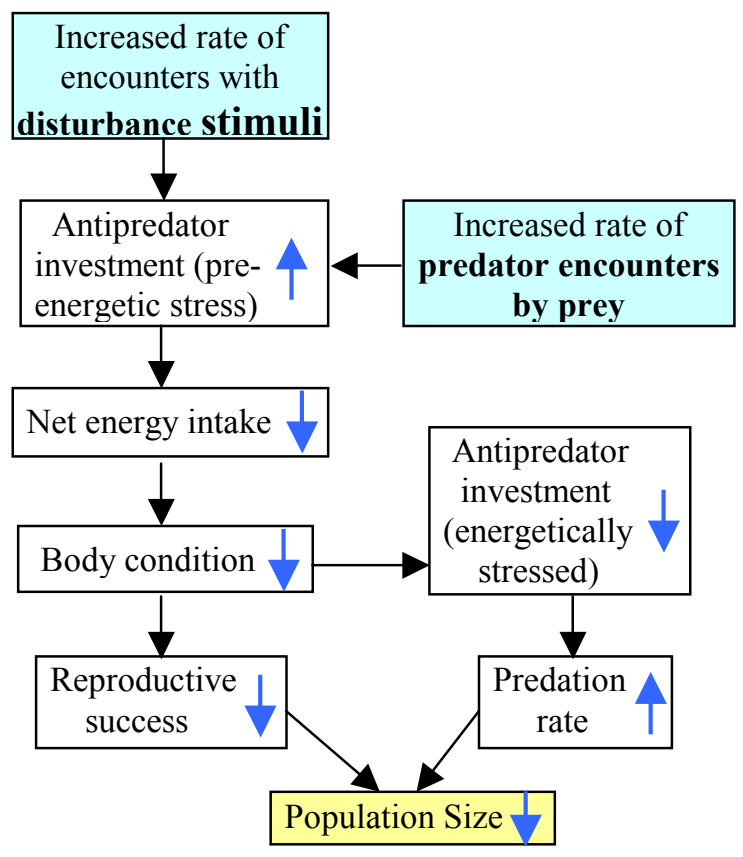

Observations of Pink-footed Geese are consistent with this prediction. Individuals in undisturbed areas gained body mass and had a breeding success of $46 \%$. In contrast, individuals in areas where farmers consistently scared them off their fields did not gain mass and had a breeding success of 17\% (Madsen 1994).

Ungulate studies provide further evidence of indirect disturbance effects on populations. The reproductive success of mule deer (Odocoileus hemionus) experimentally disturbed by an all-terrain vehicle (Yarmoloy et al. 1988) and of caribou disturbed by low-elevation jet flights (Harrington and Veitch 1992) decreased as disturbance rates increased. For elk (Cervus elaphus) disturbed experimentally by people on foot, the ratio of young to mothers was inversely related to disturbance rate (Phillips and Alldredge 2000). These studies did not address the underlying behavioral mechanisms, but were qualitatively consistent with energetic models of the behavioral 
responses and reproduction of caribou disturbed by seismic exploration blasts (Bradshaw et al. 1998) and low-elevation military jet-fights (Luick et al. 1996).

Correlational evidence corroborates the experimental studies. Body mass and population size of barren ground caribou ( $R$. tarandus) decreased as rates of military jet overflights increased (Maier 1996). The reproductive success of mountain goats correlated negatively with the cumulative number of seismic exploration lines placed two years prior to the birthing season (each kilometer of seismic line represented 6$8 \mathrm{~km}$ of helicopter flying and 22 person-days of ground work; Joslin 1986).

A study of grizzly bears foraging on army cutworm moths (Euxoa auxiliaris) provides additional support (White et al. 1999). When disturbed by hikers, bears reduced their energy intake by an average of 12 $\mathrm{kcal} / \mathrm{min}\left(50.2 \times 10^{3} \mathrm{~kJ} / \mathrm{min}\right)$, and spent energy fleeing or acting aggressively toward hikers. The body condition and reproductive success of bears are likely to deteriorate if such reductions of net energy gain are long-term and cumulative (White et al. 1999). Similar examples exist for Snow Geese (Chen caerulescens atlantica; Bélanger and Bédard 1990).

Proper tests of reproductive impacts often will be difficult for large vertebrates, because it is often logistically not feasible to reach the large sample sizes required for adequate statistical power (e.g., Delaney et al. 1999).

\section{INDIRECT EFFECTS ON COMMUNITIES}

Facilitating predation by natural predators on vulnerable young is one way in which disturbance stimuli might negatively impact one trophic level while having a positive effect on another (see Parental Investment). Other community-level effects derive from predation risk affecting the distribution of foragers and, consequently, the foragers' influence on the density of their own prey. For example, when animals spend less time foraging in risky places, they consume a lower proportion of available resources in the area (e.g., Milinski 1985, Morris and Davidson 2000), which could have cascading effects at lower trophic levels (e.g., Chase 1998). Similarly, herbivores may consume a lower proportion of the plant biomass available in the vicinity of a disturbance center (e.g., roads; Gill et al. 1996, Nellemann et al. 2001, Vistness and Nellemann 2001). Thus, human activities can indirectly affect plant community structure by influencing the distribution and intensity of herbivory.

Community effects could also become manifest when 'fear' depletes a prey patch. For example, when two predators share a common prey, the hunting activities of Predator A might increase prey wariness (e.g., forcing it to spend more time in a refuge, increasing aggregation), thereby lowering the foraging success of Predator B (Crowder et al. 1997, Sih et al. 1998, Brown et al. 1999). In the case of disturbance, an analogous situation might arise when fish schools dive deeper to evade motorized vessels (e.g., Gerlotto and Fréon 1992), forcing aquatic predators that breathe air (e.g., cetaceans and seabirds) to increase their foraging costs through deeper dives.

Kilgo et al. (1998) hypothesize that human disturbance might facilitate predation by Florida panthers (Felis concolor coryi) on white-tailed deer (Odocoileus virginianus). The deer respond to hunting activities by shifting away from roads and open habitats and by increasing their nocturnal activity, which might increase their encounter rates with panthers (Kilgo et al. 1998). However, the predation rate might not necessarily increase with encounter rate (see Lima and Dill 1990, Abrams 1993). At least until the risk of starvation becomes high (Sinclair and Arcese 1995; see Fig. 1), deer can invoke an enhanced state of alertness (e.g., higher vigilance levels, larger and tighter groups) that might counteract increases in encounter rates. It is plausible that deer hunting activities could, in fact, decrease the hunting success of panthers (see Brown et al. 1999).

\section{WHY INVOKE THE RISK-DISTURBANCE HYPOTHESIS?}

Hundreds of useful and analytically sophisticated studies already address the effects of disturbance stimuli on animals without invoking the riskdisturbance hypothesis, or indeed any other theoretical framework, and many of them test predictions similar to those discussed here. So what is gained by formalizing and applying the risk-disturbance hypothesis? Although in some cases little might be gained, we argue that the hypothesis often will enhance a study's design and conservation value.

Some predictions regarding fleeing and vigilance are intuitive, and many studies address them at some level, although usually without formalizing them (Tables 1 
and 2). Two types of predictions, however, are unlikely to be made a priori without a predation risk framework. First, there appear to be few studies that test how factors related to natural predation risk combine with the characteristics of disturbance stimuli (Prediction D in Tables 1 and 2). Although such predictions may not be relevant to all systems, not testing them will limit the explanatory power of some analyses. Second, it also appears rare for disturbance studies to consider how fleeing responses are affected by resource distribution or by environmental factors that affect locomotion costs (Prediction F of Table 1); none of the studies we reviewed did so a priori. Not considering this prediction may result in a large proportion of unexplained variability and may limit interpretation of the energetic costs of a given disturbance (see Ydenberg and Dill 1986).

In the case of habitat selection, the risk-disturbance hypothesis is not necessary for the intuitive prediction that disturbed animals will shift habitats when aversive disturbance is long term. A predation risk framework is more likely to provide an explicit focus for quantifying lost access to resources, but still is not essential (Table 3). The main issue arises when lack of habitat shifts is interpreted as no disturbance impact. As Gill et al. (2001) argued, there is a danger here of compromising the conservation implications of a study; animals that do not shift habitats simply may have no alternative place worth going to. If forced to remain in the disturbed habitat, their activity budgets probably will be disrupted.

In the case of mate acquisition and parental investment, studies not grounded on predation risk and life-history theory are unlikely to explain mechanisms behind interspecific differences in how disturbance stimuli affect mating displays, or why there is individual variability in how disturbance stimuli affects parental care. Not surprisingly, we found few data to assess our predictions.

Several studies did not need predation risk theory to make notable advances toward predicting and quantifying disturbance effects on population dynamics. We suggest that the risk-disturbance hypothesis, however, would increase the scope of models by ensuring that underlying mechanisms are considered a priori. In particular, none of the reviewed studies considered risk of starvation and predationsensitive foraging (see Sinclair and Arcese 1995). In the case of community dynamics, the territory is wide open for disturbance studies, and a predation risk framework would be fruitful for guiding predictions. For instance, the model of Gill et al. (1996) could easily be modified to consider the perspective of the plant community, rather than of the herbivore. It was not surprising that we did not come across studies addressing how disturbance increases the baseline level of wariness of a prey species, and therefore indirectly reduces the hunting success of a predator that may be more tolerant of disturbance (see Brown et al. 1999).

At a very practical level, many disturbance studies begin by measuring myriad environmental and biological variables, and go through complex exploratory statistics to reduce the number of factors that would fit a parsimonious model. Clearly, a theoretical framework would focus predictions from the outset, streamline fieldwork and analyses, and increase the generality of results. We suggest that this approach would save time and money for conservation agencies because general predictions would shorten the path toward effective mitigation measures that do not over-regulate human activities.

Although we generally found that literature examples were consistent with predictions of the riskdisturbance hypothesis, some inconsistencies did arise, indicating that much stimulating work lies ahead for refining the concepts. We hope that our discussion stimulates a wider application of predation risk theory, as well as explicit tests of its predictions.

Responses to this article can be read online at: http://www.consecol.org/Journal/vol6/iss 1/art11/responses/i ndex.htmi.

\section{Acknowledgments:}

A. Frid was supported by a PGS-B scholarship from NSERC Canada. L. M. Dill's research is supported by NSERC Canada grant A6869. We thank Bernie Crespi, Ian Hamilton, and anonymous reviewers for critiquing earlier drafts. We also thank Darren Witt for producing the loom visualization.

\section{LITERATURE CITED}

Abrams, P. A. 1993. Why predation rate should not be proportional to predator density. Ecology 74:726-733.

Allen, M. C., and A. J. Read. 2000. Habitat selection of foraging bottlenose dolphins in relation to boat density near Clearwater, Florida. Marine Mammal Science 16:815-824.

Anderson, D. W. 1988. Dose-response relationship between human disturbance and brown pelican breeding success. Wildlife Society Bulletin 16:339-345. 
Bélanger, L., and J. Bédard. 1990. Energetic cost of maninduced disturbance to staging snow geese. Journal of Wildlife Management 54:36-41.

Berger, J. 1991. Pregnancy incentives, predation constraints and habitat shifts: experimental and field evidence for wild bighorn sheep. Animal Behaviour 41:6177.

Berger J., D. Daneke, J. Johnson, and S. H. Berwick. 1983. Pronghorn foraging economy and predator avoidance in a desert ecosystem: implications for the conservation of large mammalian herbivores. Biological Conservation 25:193-208.

Bleich, V. C., R. T. Bowyer, A. M. Pauli, M. C. Nicholson, and R. W. Anthes. 1994. Mountain sheep (Ovis canadensis) and helicopter surveys: ramifications for the conservation of large mammals. Biological Conservation 70:1-7.

Bonenfant, M., and D. L. Kramer. 1996. The influence of distance to burrow on flight initiation distance on the woodchuck, Marmota monax. Behavioral Ecology 7:299303.

Born, E. W., F. F. Riget, R. Dietz, and D. Andriashek. 1999. Escape responses of hauled out ringed seals Phoca hispida to aircraft disturbance. Polar Biology 21:171-178.

Bouskila, A., and D. T. Blumstein. 1992. Rules of thumb for predation hazard assessment: predictions from a dynamic model. American Naturalist 139:161-176.

Bradshaw, C. J. A., S. Boutin, and D. M. Hebert. 1998. Energetic implications of disturbance caused by petroleum exploration to woodland caribou. Canadian Journal of Zoology 76:1319-1324.

Brown, J. S., J. W. Laundre, and M. Gurung. 1999. The ecology of fear: optimal foraging, game theory, and trophic interactions. Journal of Mammalogy 80:385-399.

Buckingham, C. A., L. W. Lefebvre, J. M. Schaefer, and H. I. Kochman. 1999. Manatee response to boating activity in a thermal refuge. Wildlife Society Bulletin 27:514-522.

Burger, J. 1998. Effects of motorboats and personal watercraft on flight behavior over a colony of common terns. Condor 100:528-534.

Burger, J., and M. Gochfeld. 1981. Discrimination of the threat of direct versus tangential approach to the nest by incubating herring and great black-backed gulls. Journal of Comparative and Physiological Psychology 95:676-684.

Burger, J., and M. Gochfeld. 1990. Risk discrimination of direct versus tangential approach by basking black iguanas (Ctenosaura similis): variation as a function of human exposure. Journal of Comparative Psychology 104:388-394.
Burger, J., and M. Gochfeld. 1998. Effects of ecotourists on bird behaviour at Loxahatchee National Wildlife Refuge, Florida. Environmental Conservation 25:13-21.

Chase, J. M. 1998. Central-place forager effects on food web dynamics and spatial pattern in northern California meadows. Ecology 79:1236-1245.

Clark, C. W., and R. C. Ydenberg. 1990. The risks of parenthood. I. General theory and applications. Evolutionary Ecology 4:21-34.

Clutton-Brock, T., and C. Godfray. 1991. Parental investment. Pages 234-262 in J. R. Krebs and N. B. Davies, editors. Behavioural ecology: an evolutionary approach. Third edition. Blackwell Scientific Publications, Oxford, UK.

Cooper, W. E. 1997. Threat factors affecting antipredatory behavior in the broad-headed skink (Eumeces laticeps): repeated approach, change in predator path, and predator's field of view. Copeia 1997:613-619.

Cooper, W. E. 1998. Direction of predator turning, a neglected cue to predation risk. Behaviour 135:55-64.

Côté, S. D., and C. Beaudoin. 1997. Grizzly bear (Ursus arctos) attacks and nanny-kid separation on mountain goats (Oreamnos americanus). Mammalia 6:614-617.

Crowder, L. B., D. D. Squires, and J. A. Rice. 1997. Nonadditive effects of terrestrial and aquatic predators on juvenile estuarine fish. Ecology 78:1796-1804.

Delaney, D. K., T. G. Grubb, P. Beier, L. L. Pater, and H. Reiser. 1999. Effects of helicopter noise on Mexican Spotted Owls. Journal of Wildlife Management 63:60-76.

de la Torre S., C. T. Snowdon, and M. Bejarano. 2000. Effects of human activities on wild pygmy marmosets in Ecuadorian Amazonia. Biological Conservation 94:153163.

Dill, L. M. 1974a. The escape response of the zebra danio (Brachydanio rerio). I. The stimulus for escape. Animal Behaviour 22:711-722.

Dill, L. M. 1974b. The escape response of the zebra danio (Brachydanio rerio). II. The effect of experience. Animal Behaviour 22:723-730.

Dill, L. M, and R. Houtman. 1989. The influence of distance to refuge on flight initiation distance in the gray squirrel (Sciurus carolinensis). Canadian Journal of Zoology 67:233-235.

Duchesne M., S. Côté, and C. Barrette. 2000. Responses of woodland caribou to winter ecotourism in the Charlevoix 
Biosphere Reserve, Canada. Biological Conservation 96:311-317.

Dyer S. J., J. P. O'Neill, S. M. Wasel, and S. Boutin. 2001. Avoidance of industrial development by woodland caribou. Journal of Wildlife Management 65:531-542.

Edwards, J. 1983. Diet shifts in moose due to predator avoidance. Oecologia 60:185-189.

Elgar, M. A. 1989. Predator vigilance and group size in mammals and birds: a critical review of the empirical evidence. Biological Reviews of the Cambridge Philosophical Society 64:12-33.

Frid, A. 2001a. Fleeing decisions by Dall's sheep exposed to helicopter overflights. Biennial Symposium of the Northern Wild Sheep and Goat Council 12:153-169.

Frid, A. 2001b. Behavioral responses by Dall's sheep to overflights by fixed-wing aircraft. Biennial Symposium of the Northern Wild Sheep and Goat Council 12:170-185.

Galicia, E., and G. A. Baldassarre. 1997. Effects of motorized tourboats on the behavior of non-breeding American flamingos in Yucatan, Mexico. Conservation Biology 11:1159-1165.

Gerlotto, F., and P. Fréon. 1992. Some elements on vertical avoidance of fish schools to a vessel during acoustic surveys. Fisheries Research 14:251-259.

Ghalambor, C. K., and T. E. Martin. 2000. Parental investment strategies in two species of nuthatch vary with stage-specific predation risk and reproductive effort. Animal Behaviour 60:263-267.

Gill J. A., K. Norris, and W. J. Sutherland. 2001. Why behavioural responses may not reflect the population consequences of human disturbance. Biological Conservation 97:265-268.

Gill, J. A., and W. J. Sutherland. 2000. Predicting the consequences of human disturbance from behavioural decisions. Pages 51-64 in L. M. Gosling and W. J. Sutherland, editors. Behaviour and Conservation. Cambridge University Press, Cambridge, UK.

Gill, J. A., W. J. Sutherland, and A. R. Watkinson. 1996. A method to quantify the effects of human disturbance on animal populations. Journal of Applied Ecology 33:786-792.

Gilliam, J. F., and D. F. Fraser. 1987. Habitat selection under predation hazard: test of a model with foraging minows. Ecology 68:1856-1862.

Gutzwiller, K. J., R. T. Wiedemann, K. L. Clements, and S. H. Anderson. 1994. Effects of human intrusion on song occurrence and singing consistency in subalpine birds. Auk 111:28-37.

Hamr, J. 1988. Disturbance behaviour of chamois in an alpine tourist area of Austria. Mountain Research and Development 8:65-73.

Harrington, F. H., and A. M. Veitch. 1992. Calving success of woodland caribou exposed to low-level jet fighter overflights. Arctic 45:213-218.

Hik, D. S. 1995. Does risk of predation influence population dynamics? Wildlife Research 22:115-129.

Hugie, D. M., and L. M. Dill. 1994. Fish and game: a game theoretic approach to habitat selection by predators and prey. Journal of Fish Biology 45:151-169.

Joslin, G. 1986. Mountain goat population changes in relation to energy exploration along Montana's Rocky Mountain front. Pages 253-266 in G. Joslin, editor. Proceedings o the Fifth Biennial Symposium of the Northern Wild Goat and Sheep Council. Montana Department of Fish, Wildlife and Parks. Missoula, Montana, USA.

Kålås, J. A., P. Fiske, and S. A. Sæther. 1995. The effect of mating probability on risk taking: an experimental study in lekking great snipe. American Naturalist 146:59-71.

Kilgo, J. C., R. F. Labisky, and D. E. Fritzen. 1998. Influences of hunting on the behavior of white-tailed deer: implications for conservation of the Florida panther. Conservation Biology 12:1359-1364.

Knapton, R. W., S. A. Petrie, and G. Herring. 2000. Human disturbance of diving ducks on Long Point Bay, Lake Erie. Wildlife Society Bulletin 28:923-930.

Komdeur, J., and R. K. H. Kats. 1999. Predation risk affects trade-offs between nest guarding and foraging in Seychelles warblers. Behavioral Ecology 10:648-658.

Lafferty, K. 2001. Disturbance to wintering western snowy plovers. Biological Conservation 101:315-325.

Lima, S. L. 1998. Stress and decision making under the risk of predation: recent developments from behavioral, reproductive, and ecological perspectives. Advances in the Study of Behavior 27:215-290.

Lima, S. L., and L. M. Dill. 1990. Behavioural decisions made under the risk of predation. Canadian Journal of Zoology 68:619-640.

Lima, S. L., and P. A. Zollner. 1996. Towards a behavioral ecology of ecological landscapes. Trends in Ecology and Evolution 11:131-135. 
Linnell, J. D. C., J. E. Swenson, R. Andersen, and B. Barnes. 2000. How vulnerable are denning bears to disturbance? Wildlife Society Bulletin 28:400-413.

Lord, A., J. R. Waas, and J. Innes. 1997. Effects of human activity on the behaviour of northern New Zealand dotterel (Charadrius obscurus aquilonius) chicks. Biological Conservation 82:15-20.

Luick, J. A., J. A. Kitchens, R. G. White, and S. M. Murphy. 1996. Modelling energy and reproductive costs in caribou exposed to low flying military jet aircraft. Rangifer Special Issue 9: 209-211.

Mace, R. D., J. S. Waller, T. L. Manley, L. J. Lyon, and H. Zuuring. 1996. Relationship among grizzly bears, roads, and habitat in the Swan Mountains, Montana. Journal of Applied Ecology 33:1395-1404.

Madsen, J. 1994. Impacts of disturbance on migratory waterfowl. Ibis 137:567-574.

Madsen, J. 1998. Experimental refuges for migratory waterfowl in Danish wetlands. II. Tests of hunting disturbance effects. Journal of Applied Ecology 35:398-417.

Magnhagen, C. 1991. Predation risk as a cost of reproduction. Trends in Ecology and Evolution 6:183-186.

Maier, J. A. K. 1996. Ecological and physiological aspects of caribou activity and response to aircraft overflights. Disseration. University of Alaska, Fairbanks, Alaska, USA.

McNamara, J. M., and A. I. Houston. 1987. Starvation and predation as factors limiting population size. Ecology 68: $1515-1519$.

McTaggart-Cowan, I. 1974. Management implications of behaviour in the large herbivorous mammals. Pages 921934 in V. Geist and F. Walther, editors. The behaviour of ungulates and its relation to management. Volume II. IUCN (International Union for the Conservation of Nature), Morges, Switzerland.

Milinski, M. 1985. Risk of predation taken by parasitised fish under competition for food. Behaviour 93:203-216.

Morris, D. W., and D. L. Davidson. 2000. Optimally foraging mice match patch use with habitat differences in fitness. Ecology 81:2061-2066.

Nellemann, C., and R. D. Cameron. 1998. Cumulative impacts of an evolving oil-field complex on the distribution of calving caribou. Canadian Journal of Zoology 76:14251430.

Nellemann, C., P. Jordøy, O.-G. Støen, and O. Strand. 2000. Cumulative impacts of tourist resorts on wild reindeer (Rangifer tarandus tarandus) during winter. Arctic 53:9-17.
Nellemann C., I. Vistness, and P. J. Strand. 2001. Winter distribution of wild reindeer in relation to power lines, roads, and resorts. Biological Conservation 101:351-360.

Nette, T., D. Burles, and M. Hoefs. 1984. Observations of golden eagle (Aquila chrysaetos) predation on Dall sheep lambs. Canadian Field Naturalist 98:252-254.

Papouchis C., F. J. Singer, and W. B. Sloan. 2001. Responses of desert bighorn sheep to increased human recreation. Journal of Wildlife Management 65:573-582.

Phillips, G. E., and A. W. Alldredge. 2000. Reproductive success of elk following disturbance by humans during calving season. Journal of Wildlife Management 64:521530 .

Piatt, J. F., B. D. Roberts, W. W. Lidster, J. L. Wells, and S. A. Hatch. 1990. Effects of human disturbance on breeding Least and Crested Auklets at St. Lawrence Island, Alaska. Auk 107:342-350.

Ryan, M. J. 1985. The tungara frog: a study in sexual selection and communication. University of Chicago Press, Chicago Illinois, USA.

Sih, A., G. Englund, and D. Wooster. 1998. Emergent impacts of multiple predators on prey. Trends in Ecology and Evolution 13:350-355.

Sinclair, A. R. E., and P. Arcese. 1995. Population consequences of predation-sensitive foraging: the Serengeti wildebeest. Ecology 76:882-891.

Steidl, R. J., and R. G. Anthony. 1996. Responses of Bald Eagles to human activity during the summer in interior Alaska. Ecological Applications 6:482-491.

Steidl, R. J., and R. G. Anthony. 2000. Experimental effects of human activity on breeding Bald Eagles. Ecological Applications 10:258-268.

Stockwell, C. A., G. C. Bateman, and J. Berger. 1991. Conflicts in national parks: a case study of helicopters and bighorn sheep time budgets at the Grand Canyon. Biological Conservation 56:317-328.

Swarthout, E. C. H., and R. J. Steidl. 2001. Flush responses of Mexican spotted owls to recreationists. Journal of Wildlife Management 65:312-317.

Sweitzer, R. A. 1996. Predation or starvation: consequences of foraging decisions by porcupines (Erethizon dorsatum). Journal of Mammalogy 77:1068-1077.

Tremblay, J., and L. Ellison. 1979. Effects of human disturbance on breeding of Black-crowned Night Herons. Auk 96:364-369. 
Verhulst S., K. Oosterbeek, and B. J. Ens. 2001. Experimental evidence of effects of human disturbance on foraging and parental care in oystercatchers. Biological Conservation 101:375-380.

Vistness I., and C. Nellemann. 2001. Avoidance of cabins, roads, and power lines by reindeer during calving. Journal of Wildlife Management 65:915-925.

Walther, F. R. 1969. Flight behaviour and avoidance of predators in Thomson's gazelle (Gazella thomsoni: Guenther 1884). Behaviour 34:184-221.

Ward, C., and B. S. Low. 1997. Predictors of vigilance for American Crows foraging in an urban environment. Wilson Bulletin 109:481-489.

Ward, D. H., R. A. Stehn, W. P. Erickson, and D. V. Derksen. 1999. Response of fall-staging brant and Canada geese to aircraft overflights in southwestern Alaska. Journal of Wildlife Management 63:373-381.
White, D., Jr., K. C. Kendall, and H. D. Picton. 1999. Potential energetic effects of mountain climbers on foraging grizzly bears. Wildlife Society Bulletin 27:146-151.

White, R. G. 1983. Foraging patterns and their multiplier effects on productivity of northern ungulates. Oikos 40:377384.

Yarmoloy, C., M. Bayer, and V. Geist. 1988. Behavior responses and reproduction of mule deer, Odocoileus hemionus, does following experimental harassment with an all-terrain vehicle. Canadian Field Naturalist 102:425-429.

Ydenberg, R. C., and L. M. Dill. 1986. The economics of fleeing from predators. Advances in the Study of Behavior 16:229-249.

Zollner, P. A., and S. L. Lima. 1997. Landscape level perceptual abilities in white-footed mice: perceptual range and the detection of forested habitat. Oikos 80:51-60.

Appendix 1. An example of a generalized fright stimulus. Many animals initiate flight when the rate of change of angle subtended by an approaching object ("loom") exceeds some threshold. To repeat the animation, please refresh your browser or click the image. (For pdf version readers: Go to http://www.consecol.org/Journal/vol6/iss1/art11/appendix1.html to view this animated image)

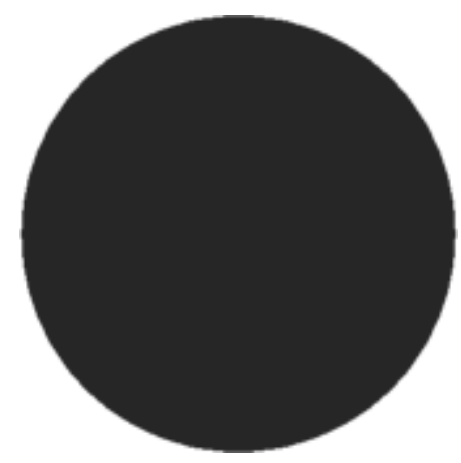

